\title{
Inhibitory Effect on $\beta$-Hexosaminidase Release from RBL-2H3 Cells of Extracts and Some Pure Constituents of Benchalokawichian, a Thai Herbal Remedy, Used for Allergic Disorders
}

\author{
Thana Juckmeta, ${ }^{1}$ Pakakrong Thongdeeying, ${ }^{2}$ and Arunporn Itharat ${ }^{2,3}$ \\ ${ }^{1}$ Faculty of Medicine, Thammasat University, Rangsit Campus, Khlong Luang, Pathum Thani 12120, Thailand \\ ${ }^{2}$ Department of Applied Thai Traditional Medicine, Faculty of Medicine, Thammasat University, Rangsit Campus, Khlong Luang, \\ Pathum Thani 12120, Thailand \\ ${ }^{3}$ Center of Excellence on Applied Thai Traditional Medicine Research (CEATMR), Faculty of Medicine, Thammasat University, \\ Rangsit Campus, Khlong Luang, Pathum Thani 12120, Thailand
}

Correspondence should be addressed to Arunporn Itharat; iarunporn@yahoo.com

Received 3 November 2014; Revised 20 November 2014; Accepted 22 November 2014; Published 16 December 2014

Academic Editor: Il-Moo Chang

Copyright (C) 2014 Thana Juckmeta et al. This is an open access article distributed under the Creative Commons Attribution License, which permits unrestricted use, distribution, and reproduction in any medium, provided the original work is properly cited.

\begin{abstract}
Introduction. Benchalokawichian (BCW), a Thai traditional herbal formulation, has long been used as antipyretic and to treat skin disorders. It comprises roots from five herbs: Ficus racemosa, Capparis micracantha, Clerodendrum petasites, Harrisonia perforata, and Tiliacora triandra. This polyherbal remedy has recently been included in the Thailand National List of Essential Medicines (Herbal Products list). Methodology. A Bioassay-guided fractionation technique was used to evaluate antiallergy activities of crude extracts, and those obtained by the multistep column chromatography isolation of pure compounds. Inhibitory effect on the release of $\beta$-hexosaminidase from RBL-2H3 cells was used to determine antiallergic activity. Results. Two pure compounds from BCW formulation showed higher antiallergic activity than crude or semipure extracts. Pectolinarigenin showed the highest antiallergic activity, followed by $O$-methylalloptaeroxylin, with $\mathrm{IC}_{50}$ values of $6.3 \mu \mathrm{g} / \mathrm{mL}$ and $14.16 \mu \mathrm{g} / \mathrm{mL}$, respectively. Moreover, the highest activities of pure compounds were significantly higher than chlorpheniramine $(16.2 \mu \mathrm{g} / \mathrm{mL})$. Conclusions. This study provides some support for the use of BCW in reducing itching and treatment of other skin allergic disorders. The two isolated constituents exhibited high antiallergic activity and it is necessary to determine their mechanism of action. Further phytochemical and safety studies of pure compounds are required before development of these as antiallergy commercial remedies.
\end{abstract}

\section{Introduction}

Allergic diseases are manifested as hyperresponsiveness to allergenic environmental substances in the various target organs of the body (skin, nose, lung, gastrointestinal tract, etc.) and involve both IgE-mediated and non-IgE-mediated components $[1,2]$. Exposure to allergenic materials results in production, by B cells, of a multitude of antibodies, collectively called immunoglobulins (Ig) that are antigen-specific. The allergic reaction starts when immunoglobulin $\mathrm{E}$ binds to specific receptors (FcRI) on the surface of mast cells and basophils $[3,4]$, which in turn induces degranulation of the cells and release of mediators such as histamine, leukotrienes, serotonin, and platelet activating factors [5-7]. Histamine is the main cause of many of the symptoms of allergies, such as runny nose, sneezing, and itching. Histamine also contributes to the progression of allergic-inflammatory responses by enhancement of the secretion of proinflammatory cytokines [8]. Although antihistamines are the first drugs of choice for treatment of many types of allergic disorders, they do have certain side effects. A large proportion $(70-95 \%)$ of the world's population still relies on herbal medicines for primary health care [9]. Therefore, there is a continuous search for newer and better drugs for allergy treatment, including evaluation of traditional herbal remedies [10]. Since IgEs play an important role in the allergic reaction, it has been 
suggested that the way to treat and prevent allergic diseases is to block the activity of IgE response [11-13].

Benchalokawichian (BCW) is a Thai traditional medicine formulation containing parts from roots of five plants in equal amounts: Ficus racemosa Linn. (Moraceae), Capparis micracantha DC. (Capparidaceae), Clerodendrum petasites S. Moore. (Lamiaceae), Harrisonia perforata Merr. (Simaroubaceae), and Tiliacora triandra Diels. (Menispermaceae). It has long been used for relief of fever and to treat skin rash. This formulation is included in the Thailand National List of Essential Medicines [14]. It has also been used for prevention of influenza H1N1 infections and in recent years this remedy has been used to treat acne, skin rashes, and other similar skin disorders.

The polyherbal formulation BCW has not been systematically studied before, but there are numerous previous reports on the chemical constituents of some individual plants in this herbal remedy. Harrisonia perforata leaves, fruits, braches, and roots were shown to contain several chromones, limonoids, triterpenoids, and prenylated polyketides including harrisotone $\mathrm{A}-\mathrm{E}$, haperforine $\mathrm{A}$, haperforine $\mathrm{E}, 12$-desacetylhaperforine A, haperforine $\mathrm{C} 2$, haperforine $\mathrm{F}$, haperforine $\mathrm{G}$, Foritin, harrisonol A, peucenin-7-methylether, O-methylalloptaeroxylin, perforatic acid, eugenin, saikochromone A, greveichromenol, and perforamone A-D [15]. Other reported constituents are $\beta$-sitosterol, obacunone, herteropeucenin-7methyl ether, perforatic acid and harrisonin [16-19], harperforatin, harperfolide, and harperamone [20]. Tiliacora triandra has been reported to contain alkaloids, especially bisbenzylisoquinoline alkaloids, including tiliacorinine, tiliacorine, nortiliacorinine, and others [21-23]. Ficus racemosa has been reported to contain tannins, flavonoids, coumarins, phenolic compounds, glycosides, and phytosterols [24, 25].

Currently the antipyretic and anti-inflammatory activities of BCW have only been studied in vivo in rats [26,27]. The antimicrobial activity of ethanolic and water extracts of BCW has recently been reported $[28,29]$. There are no other in vitro studies on antioxidant, antiallergy, or anti-inflammatory activities on BCW. However, a recent study on fruits of $H$. perforata has demonstrated that organic extracts exhibited high antioxidant activity by the DPPH method but failed to show any cytotoxicity against human myelogenous leukemia (K562) and human cancer (SGC-7901), cell lines in vitro by the MTT method [30]. Another report has also described the antioxidant activity in extracts of fruits of $H$. perforata by the DPPH method [31]. The results of in vivo rats suggest that $H$. perforata bark aqueous extracts does not cause acute and subchronic toxicities [32].

Benchalokawichian remedy has yet not been thoroughly studied, either in vitro or in vivo. Its recent inclusion in the Thailand National List of Essential Medicines has encouraged us to carry out systematic phytochemical and bioactivity assessment of crude extracts. Singharachai et al. studied morphological characters including macroscopic, microscopic examination, and pharmacognostic parameters and investigated 3D-HPLC fingerprint profile [33]. We also report the use of bioactivity-guided isolation of semipure and some pure constituents from this polyherbal remedy. In this preliminary study we have concentrated on antiallergic activity and on limited number of pure compounds. It is hoped that furthermore detailed studies of this type, along with safety studies in animals, will provide data that may allow the investigation of its clinical efficacy in controlled clinical trials for some of the conditions it is currently used for in Thailand by Thai Traditional medicine (TTM) practitioners.

\section{Materials and Methods}

2.1. Chemicals, Reagents, and Instrumentation. RBL-2H3 Rat basophilic leukemia cell line was from American Type Culture Collection (ATCC CRL-2256, VA, USA); fetal bovine serum (FBS), trypsin-EDTA, and trypan blue were purchased from Gibco (OK, USA). Minimum essential medium (MEM), penicillin-streptomycin $(\mathrm{P} / \mathrm{S})$, and phosphate buffer saline (PBS) were purchased from Biochrom (MA, Germany). 4Nitrophenyl $N$-acetyl- $\beta$-D-glucosaminide (PNAG), antidinitrophenylated bovine albumin (DNP-BSA), anti-DNP IgE (monoclonal anti-DNP), ketotifen fumarate, and chlorpheniramine were purchased from Sigma (MO, USA). Dimethyl sulfoxide (DMSO) was purchased from Fluka (Munich, Germany). Calcium chloride dehydrate, magnesium chloride $6 \mathrm{H}_{2} \mathrm{O}$, potassium chloride, and sodium carbonate were purchased from Merck (Darmstadt, Germany). Piperazine$N, N^{\prime}$-bis(2-ethanesulfonic acid) (PIPES) was purchased from Amresco (OH, USA). Sodium chloride and sodium hydroxide (analytical grade) were purchased from Univar (Ajax Finechem, Australia). Sodium bicarbonate was purchased from BDH (Poole, U.K.). The solvents for analysis, hexane, chloroform, ethyl acetate, and methanol (analytical grades) were purchased from RCI Labscan (Bangkok, Thailand). Sterile water was obtained by purification using a Milli Q system from Millipore (Bedford, MA, USA). Silica gel 60 grade numbers 1.07734 and 1.09385 (70-230 mesh and 230400 mesh) and TLC silica gel $60 \mathrm{~F}_{254}$ were purchased from Merck (Darmstadt, Germany). Chromatographic column $(4.5 \times 54 \mathrm{~cm}$, glass) was purchased from Becthai (Bangkok, Thailand). $\mathrm{CO}_{2}$ humidified incubator was purchased from Shellab (OR, USA). Laminar air flow cabinet was purchased from Boss tech (Bangkok, Thailand). Microplate reader was purchased from BioTek (VT, USA).

2.2. Plant Materials. Roots of five plants were collected from Dan-Chang, Suphan Buri Province, in Thailand in March 2012. Authentication of plant materials was by comparison against specimens deposited at the herbarium of Southern Center of Thai Medicinal Plants, Faculty of Pharmaceutical Science, Prince of Songkla University, Songkla, Thailand.

2.3. Preparation of the Extracts. The roots from each of these five plants were cleaned, cut in small pieces, and dried at $50^{\circ} \mathrm{C} 24 \mathrm{~h}$. Each dried plant material was powdered using an electric grinder ( 40 mesh particle size). Five plant powders in the same ratio were mixed to provide the BCW remedy. BCW and each of the five plants were macerated with 95\% ethanol, filtered with whatman number 1 and solvent removed using a rotary evaporator under reduced pressure $\left(40^{\circ} \mathrm{C}\right)$ to obtain the dry ethanolic extracts. These extracts were further dried 
to constant weight in a vacuum desiccator. All extracts were kept at $-20^{\circ} \mathrm{C}$ until required for further use.

\subsection{Preparation of Semipure Extracts and Isolation of Pure Compounds}

2.4.1. Vacuum Liquid Chromatography (VLC). Bioassayguided fractionation was used to isolate the pure compounds by the following modified method of Tewtrakul and Itharat [34]. The BCW ethanolic extract $(50.46 \mathrm{~g})$ was subjected to silica vacuum liquid chromatography (VLC), using five solvent systems of increasing polarity; hexane $(1500 \mathrm{~mL})$, hexane: chloroform $(1: 1,2000 \mathrm{~mL})$, chloroform $(2500 \mathrm{~mL})$, chloroform : methanol $(1: 1,2500 \mathrm{~mL})$, and methanol $(2000 \mathrm{~mL})$. The VLC column was packed with silica gel 60 (mesh 230-400), the crude extract was applied on top of the column, then they were eluded with these five different solvents. The solvent in each fraction (fractions 15) was removed by rotary evaporator $\left(40^{\circ} \mathrm{C}\right)$, and the dry semipure extract further dried to constant weight.

2.4.2. Further Purification by Gravity Feed CC to Isolate Pure Compound. The fraction 3 (chloroform, $5.02 \mathrm{~g}$ ) which exhibited the highest antiallergy activity was rechromatographed by column chromatography $(4.50 \mathrm{~cm}$ diameter and $54 \mathrm{~cm}$ length) using silica gel G (70-230 mesh), with gravity feed of the following solvents in sequence: hexane: chloroform $(1: 1$, $500 \mathrm{~mL})$; chloroform $(300 \mathrm{~mL})$; chloroform : methanol (9:1, $500 \mathrm{~mL})$; chloroform : methanol $(1: 1,200 \mathrm{~mL})$; methanol $(300 \mathrm{~mL})$. Fractions $(12 \mathrm{~mL})$ were collected during elution with each solvent (the first and the last fractions, $500 \mathrm{~mL}$ per each fraction, were not collected). Each of total fractions collected was examined by TLC.

The fraction $12(282.6 \mathrm{mg})$ was rechromatographed by column chromatograph $(3.75 \mathrm{~cm} \times 54 \mathrm{~cm})$ of silica gel grade numbers $70-230$ mesh, by eluting sequentially with solvents of increasing polarity; hexane: $\operatorname{EtOAc}(7: 3,1000 \mathrm{~mL})$; hexane: EtOAc (1:1, $400 \mathrm{~mL})$; hexane: $\operatorname{EtOAc}(3: 7,300 \mathrm{~mL})$; EtOAc $(700 \mathrm{~mL})$; EtOAc: $\mathrm{MeOH}(1: 1,100 \mathrm{~mL})$, and finally $\mathrm{MeOH}(200 \mathrm{~mL})$. Fractions $(5 \mathrm{~mL})$ were collected for each eluting solvent and all fractions were examined by TLC $\left(\mathrm{GF}_{254}\right)$.

2.4.3. Identification of Compounds 1 and 2. TLC (silica gel 60 $\mathrm{GF}_{254}$ aluminium sheets, Merck) were used to demonstrate the purity of compounds, with three different solvent systems of varying polarity and detection with anisaldehyde reagent. The structures of the isolated compounds were determined by their NMR data $\left[{ }^{1} \mathrm{H}\right.$ and ${ }^{13} \mathrm{C}$ on a Varian Unity Inova 500 spectrometer $\left(500 \mathrm{MHz}\right.$ for ${ }^{1} \mathrm{H} ; 125 \mathrm{MHz}$ for $\left.{ }^{13} \mathrm{C}\right)$ ], UV spectra [SPECORD S 100 (Analytikjena) spectrometer], and ESI mass spectra, both HRMS and LRMS, were obtained from a Agilent Technologies 1200 Binary LC System coupled to a Bruker microtof mass spectrometer.

2.5. Determination of Antiallergic Activity. Inhibitory effects on the release of $\beta$-hexosaminidase from Rat Basophilic Leukemia cell line (RBL-2H3) were evaluated by the following modified method [35]. RBL-2H3 cells were cultured in MEM medium supplemented with $15 \%$ fetal bovine serum (FBS), penicillin (100 units $/ \mathrm{mL}$ ), and streptomycin $(100 \mu \mathrm{g} / \mathrm{mL})$. The cells were seeded in 24-wells plate $(5 \times$ $10^{5}$ cells $/ \mathrm{mL}$ ) and incubated to adhere at $37^{\circ} \mathrm{C}$ in $5 \% \mathrm{CO}_{2}$ for 1.5 hour. RBL-2H3 cells were sensitized with anti-DNP IgE (antidinitrophenyl-immunoglobulin E) $(0.45 \mu \mathrm{g} / \mathrm{mL})$, and incubated at $37^{\circ} \mathrm{C}$ in $5 \% \mathrm{CO}_{2}$ for $24 \mathrm{~h}$. The cells were washed with $400 \mu \mathrm{L}$ of Siraganian buffer (buffer A) [119 mM NaCl, $5 \mathrm{mM} \mathrm{KCl}, 5.6 \mathrm{mM}$ glucose, $0.4 \mathrm{mM} \mathrm{MgCl}, 1 \mathrm{mM} \mathrm{CaCl}_{2}$, $25 \mathrm{mM}$ piperazine- $N, N^{\prime}$-bis (2-ethanesulfonic acid) (PIPES), $0.1 \%$ bovine serum albumin (BSA), and $40 \mathrm{mM} \mathrm{NaOH}$, $\mathrm{pH}$ 7.2]. An aliquot $(160 \mu \mathrm{L})$ of buffer A was added and incubation was continued for an additional $10 \mathrm{~min}$ at $37^{\circ} \mathrm{C}$. The test sample $(20 \mu \mathrm{L})$ solution was added to each well and incubated for $10 \mathrm{~min}$, followed by addition of $20 \mu \mathrm{L}$ of antigen (DNP-BSA, final concentration $10 \mu \mathrm{g} / \mathrm{mL}$ ) at $37^{\circ} \mathrm{C}$ for $20 \mathrm{~min}$ to stimulate cell degranulation. The supernatants were transferred into 96-well plate in $50 \mu \mathrm{L} /$ wells and incubated with $50 \mu \mathrm{L}$ of substrate PNAG ( $1 \mathrm{mM} p$-nitrophenyl- $N$-acetylb-D-glucosaminide) in $0.1 \mathrm{M}$ citrate buffer $(\mathrm{pH} 4.5)$ at $37^{\circ} \mathrm{C}$ for $3 \mathrm{~h}$. The reaction was stopped by adding $200 \mu \mathrm{L}$ of stop solution ( $\left.0.1 \mathrm{M} \mathrm{Na}_{2} \mathrm{CO}_{3} / \mathrm{NaHCO}_{3}, \mathrm{pH} 10.0\right)$. The absorbance was measured with a microplate reader at $405 \mathrm{~nm}$. The test samples were dissolved in dimethyl sulfoxide (DMSO), and Siraganian buffer was added for dilution (final DMSO concentration was $0.1 \%$ ). The positive controls showed clear yellow color, whereas the negative control was colorless. The samples were pale yellow to colorless, representing the percentage of inhibition antiallergic activity. Chlorpheniramine was used by positive controls. The percentage of inhibition was calculated according to the following formula:

$$
\% \text { Inhibition }=\left[1-\frac{(T-B-N)}{(C-N)}\right] \times 100 .
$$

Control $(C)$ : DNP-BSA $(+)$, Test sample (-); Test (T): DNPBSA $(+)$, Test sample $(+)$; Blank $(B)$ : DNP-BSA $(-)$, Test sample (+); Normal (N): DNP-BSA (-), Test sample (-).

2.6. Statistical Analysis. The results are based on three separate experiments. Each sample was analyzed in triplicate in any experiment. The activity values are expressed as mean \pm SD. $\mathrm{IC}_{50}$ values were calculated using the Prism Program.

\section{Results}

3.1. Yield of Crude Extracts and Fractions (F1-F5). Yields (\% $\mathrm{w} / \mathrm{w}$ ) of $95 \%$ ethanolic crude extracts of BCW remedy and its constituent were low, in range of $2-4 \%$ (see in Table 1).

The ethanolic extract of BCW (50.46g) was subjected to vacuum liquid chromatography (VLC) to obtained five semipure extracts (F1-F5). Fraction 4 (chloroform : methanol elution) showed the highest yield, followed by fraction 3 and fraction 5, with yields being $65.40 \%, 13.20 \%$, and $10.52 \%$, respectively. The yields are shown in Table 2 . All extracts and fractions were test inhibitory effects on release of $\beta$ hexosaminidase. The fractions which showed highest antiallergy activity were further subjected to purification to isolate pure compounds. 
TABLE 1: Yields (\%w/w) and voucher specimen number of Benchalokawichian formulation and constituent plants.

\begin{tabular}{lccc}
\hline Sample & Family name & Voucher specimens & \%Yield* \\
\hline Ficus racemosa Linn. & Moraceae & SKP 117 06 18 01 & $4.18 \%$ \\
Capparis micracantha DC. & Capparidaceae & SKP 391 03 13 01 & $1.89 \%$ \\
Tiliacora triandra Diels. & Menispermaceae & SKP 114202001 & $3.92 \%$ \\
Harrisonia perforata Merr. & Simaroubaceae & SKP 178 08 16 01 & $2.78 \%$ \\
Clerodendrum petasites S. Moore & Lamiaceae & SKP 202 03 09 01 & $2.20 \%$ \\
Benchalokawichian remedy (Ha-Rak) & & - & $3.59 \%$ \\
\hline
\end{tabular}

${ }^{*}$ Extraction by maceration with $95 \%$ ethanol. Yields are $\% \mathrm{w} / \mathrm{w}$ of starting dry weight of powered roots or BCW formulation.

TABLE 2: Yields (\%w/w) of fractions after VLC of the crude ethanolic extract of Benchalokawichian formulation.

\begin{tabular}{lc}
\hline Fraction; solvent system & \%Yield* \\
\hline 1; hexane & $0.06(0.002)$ \\
2; hexane : chloroform & $5.98(0.214)$ \\
3; chloroform & $13.26(0.47)$ \\
4; chloroform : methanol & $65.40(2.35)$ \\
5; methanol & $10.52(0.38)$ \\
\hline
\end{tabular}

${ }^{*}$ Yield is $\% \mathrm{w} / \mathrm{w}$ of crude ethanolic extract (values in brackets are $\% \mathrm{w} / \mathrm{w}$ expressed of DPW).

3.2. Isolation and Identification of Isolated Pure Compounds 1 and 2. The semipure extract from fraction F3 of VLC was purified using silica gel chromatogram (70-230 mesh) using solvents of increasing polarity for elution, with gravity feed of solvents. This step of purification resulted in the isolation of two pure compounds. All collected fractions were examined by TLC using anisaldehyde (in $\mathrm{H}_{2} \mathrm{SO}_{4}$ ) as detection spray. Compound 1 appeared as a yellow spot on TLC plates on heating and compound 2 appeared as yellow spot with no heating required. Compounds 1 and 2 were further identified by ${ }^{1} \mathrm{H}$ and ${ }^{13} \mathrm{C} \mathrm{NMR}$, and the structure identity confirmed by mass spectroscopy; compound 1 was pectolinarigenin and compound 2 was $O$-methylalloptaeroxylin.

On recrystallization of material from methanol afforded a crystalline pale yellow solid $(5 \mathrm{mg}$,) as compound 1 pectolinarigenin or 5,7-dihydroxy-6-methoxy-2-(4-methoxyphenyl)-4H-chromen-4-one (PubChem CID: 5320438). The molecular formula of compound 1 was proposed to be $\mathrm{C}_{17} \mathrm{H}_{14} \mathrm{O}_{6}$, as deduced from ESI mass spectra [m/z 315.0863; $(\mathrm{M}+\mathrm{H})+],{ }^{1} \mathrm{H}$ NMR $\left(500 \mathrm{MHz}, \mathrm{CDCl}_{3}\right)$, and the ${ }^{13} \mathrm{C}$ NMR $\left(125 \mathrm{MHz}, \mathrm{CDCl}_{3}\right), 17$ carbon signals observed, 10 of which correspond with 14 protons as observed from HMBC spectrum (Figure 1). NMR data is shown in Table 3.

The fraction 6 was a yellow solid (108 mg,) and was identified as compound 2 O-methylalloptaeroxylin (PubChem CID: 441968). The molecular formula of compound 2 was proposed to be $\mathrm{C}_{16} \mathrm{H}_{16} \mathrm{O}_{4}$, as deduced from ESI mass spectra $[\mathrm{m} / \mathrm{z}$ 273.1121; $(\mathrm{M}+\mathrm{H}+)],{ }^{1} \mathrm{H}$ NMR $\left(500 \mathrm{MHz}, \mathrm{CDCl}_{3}\right)$, and the ${ }^{13} \mathrm{C}$ NMR $\left(125 \mathrm{MHz}, \mathrm{CDCl}_{3}\right)$ in Table 4,16 carbon signals observed, 7 of which correspond with 16 protons as observed from $\mathrm{HMBC}$ spectrum (Figure 2).

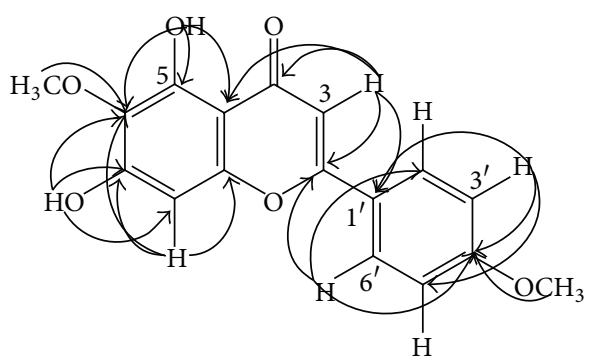

FIGURE 1: HMBC correlation of compound pectolinarigenin.

TABLE 3: NMR spectrum data $\left(500 \mathrm{MHz}\right.$ for ${ }^{1} \mathrm{H}$ and $125 \mathrm{MHz}$ for ${ }^{13} \mathrm{C}$ ) of compound 1 .

\begin{tabular}{lccc}
\hline Position & ${ }^{1} \mathrm{H}$ (mult., $J$ in Hz. $)^{\mathrm{a}}$ & ${ }^{13} \mathrm{C}$ & $\mathrm{HMBC}\left({ }^{1} \mathrm{H} \rightarrow{ }^{13} \mathrm{C}\right)$ \\
\hline 2 & - & 164.2 & \\
3 & $6.57(\mathrm{~s})$ & 103.8 & $\mathrm{C}-2, \mathrm{C}-4, \mathrm{C}-4 \mathrm{a}, \mathrm{C}-1^{\prime}$ \\
4 & - & 183.0 & \\
$4 \mathrm{a}$ & - & 105.8 & \\
5 & - & 152.1 & \\
6 & - & 130.3 & \\
7 & - & 154.9 & \\
8 & $6.59(\mathrm{~s})$ & 93.3 & $\mathrm{C}-6, \mathrm{C}-7, \mathrm{C}-8 \mathrm{a}$ \\
$8 \mathrm{a}$ & - & 153.2 & \\
$1^{\prime}$ & - & 123.6 & \\
$2^{\prime}$ & $7.83(\mathrm{dd}, 8.9,1.9)$ & 128.1 & $\mathrm{C}-2, \mathrm{C}-4^{\prime}, \mathrm{C}-6^{\prime}$ \\
$3^{\prime}$ & $7.01(\mathrm{dd}, 8.9,1.9)$ & 114.5 & $\mathrm{C}-1^{\prime}, \mathrm{C}-4^{\prime}, \mathrm{C}-5^{\prime}$ \\
$4^{\prime}$ & - & 162.6 & \\
$5^{\prime}$ & $7.01(\mathrm{dd}, 8.9,1.9)$ & 114.5 & $\mathrm{C}-1^{\prime}, \mathrm{C}-3^{\prime}, \mathrm{C}-4^{\prime}$ \\
$6^{\prime}$ & $7.83(\mathrm{dd}, 8.9,1.9)$ & 128.1 & $\mathrm{C}-2, \mathrm{C}-2^{\prime}, \mathrm{C}-4^{\prime}$ \\
$5-\mathrm{OH}$ & $13.10(\mathrm{~s})$ & & $\mathrm{C}-4 \mathrm{a}, \mathrm{C}-5, \mathrm{C}-6$ \\
$7-\mathrm{OH}$ & $6.53(\mathrm{~s})$ & & C-6, C-7, C-8 \\
$4^{\prime}-\mathrm{OCH}{ }_{3}$ & $3.90(3 \mathrm{H}, \mathrm{s})$ & 55.5 & C-4 \\
$6-\mathrm{OCH}{ }_{3}$ & $4.04(3 \mathrm{H}, \mathrm{s})$ & 60.8 & $\mathrm{C}-6$ \\
\hline & & & \\
\hline
\end{tabular}

Note. Compound 1 in $\mathrm{CDCl}_{3} ;{ }^{a}$ if not indicated; the integration of each proton signal equal to one proton.

3.3. Inhibitory Effects on Release of $\beta$-Hexosaminidase. $\mathrm{IC}_{50}$ values of antiallergic activity against release of $\beta$-hexosaminidase in RBL-2H3 cell lines are shown in Table 5. The ethanolic 


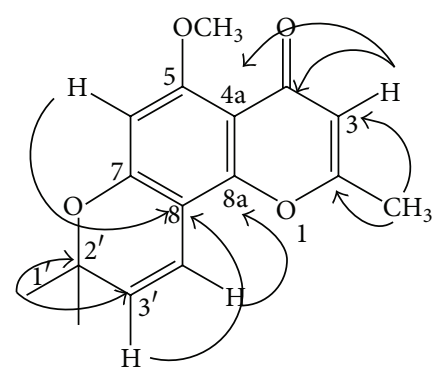

FIGURE 2: HMBC correlation of compound $O$-methylalloptaeroxylin.

TABLe 4: NMR spectrum data $\left(500 \mathrm{MHz}\right.$ for ${ }^{1} \mathrm{H}$ and $125 \mathrm{MHz}$ for ${ }^{13} \mathrm{C}$ ) of compound 2 .

\begin{tabular}{lccc}
\hline Position & ${ }^{1} \mathrm{H}$ (mult., $J$ in Hz. $)^{\mathrm{a}}$ & ${ }^{13} \mathrm{C}$ & $\mathrm{HMBC}\left({ }^{1} \mathrm{H} \rightarrow{ }^{13} \mathrm{C}\right)$ \\
\hline 2 & & 162.5 & \\
3 & $5.99(\mathrm{~s})$ & 111.8 & $\mathrm{C}-2, \mathrm{C}-2, \mathrm{C}-4, \mathrm{C}-4 \mathrm{a}$ \\
4 & & 177.5 & \\
$4 \mathrm{a}$ & & 108.5 & \\
5 & & 160.6 & \\
6 & $6.29(\mathrm{~s})$ & 96.4 & $\mathrm{C}-4 \mathrm{a}, \mathrm{C}-5, \mathrm{C}-7, \mathrm{C}-8$ \\
7 & & 157.6 & \\
8 & & 102.3 & \\
$8 \mathrm{a}$ & & 154.3 & \\
$1^{\prime} \times 2$ & $1.47(\mathrm{~s})$ & 28.2 & $\mathrm{C}-1^{\prime}, \mathrm{C}-2^{\prime}, \mathrm{C}-3^{\prime}$ \\
$2^{\prime}$ & & 77.9 & \\
$3^{\prime}$ & $5.55(\mathrm{~d}, 10.0)$ & 127.3 & $\mathrm{C}-2^{\prime}, \mathrm{C}-8$ \\
$4^{\prime}$ & $6.70(\mathrm{~d}, 10.0)$ & 115.3 & $\mathrm{C}-7, \mathrm{C}-8, \mathrm{C}-8 \mathrm{a}, \mathrm{C}-2^{\prime}$ \\
$2^{\prime}-\mathrm{CH}_{3}$ & $2.28(3 \mathrm{H}, \mathrm{s})$ & 19.6 & $\mathrm{C}-2, \mathrm{C}-3$ \\
$5-\mathrm{OCH}_{3}$ & $3.91(\mathrm{~s})$ & 56.4 & C-5 \\
\hline
\end{tabular}

Note. Compound 2 in $\mathrm{CDCl}_{3} ;{ }^{\mathrm{a}}$ if not indicated; the integration of each proton signal equal to one proton.

crude extract from $H$. perforata exhibited the most potent antiallergic activity, followed by $F$. racemosa and the polyherbal $\mathrm{BCW}$ formulation $\left(\mathrm{IC}_{50}=14.5,27.7\right.$ and $39.8 \mu \mathrm{g} / \mathrm{mL}$, resp.). C. petasites showed only moderate activity $\left(\mathrm{IC}_{50}=\right.$ $57.8 \mu \mathrm{g} / \mathrm{mL}$ ), whereas C. micracantha and T. triandra were inactive $\left(\mathrm{IC}_{50}>100 \mu \mathrm{g} / \mathrm{mL}\right)$.

The semipure extracts from fraction F3 and fraction F4 after VLC showed high inhibitory activity $\left(\mathrm{IC}_{50}\right.$ values 17.9 and $19.6 \mu \mathrm{g} / \mathrm{mL}$, resp.). Other semipure extracts (F2 and F5) had moderate activity, whereas the hexane extract (F1) was not tested.

Pectolinarigenin and $\mathrm{O}$-methylalloptaeroxylin exhibited the highest antiallergic activity, with $\mathrm{IC}_{50}$ values of 6.3 and $14.2 \mu \mathrm{g} / \mathrm{mL}(20.1$ and $51.8 \mu \mathrm{M})$, respectively. These two compounds show higher inhibitory effect than chlorpheniramine, positive control $\left(\mathrm{IC}_{50}=16.2 \mu \mathrm{g} / \mathrm{mL}, 58.8 \mu \mathrm{M}\right)$.

\section{Discussion and Conclusions}

This study has isolated for the first time two pure compounds from the ethanolic extract of BCW formulation and identified them as pectolinarigenin (compound 1) and $O$ methylalloptaeroxylin (compound 2), which have not presented on 3D-HPLC chromatogram in previous study [33]. Compound 2 has previously been isolated from branches of $H$. perforata [36, 37]. In a recent study Choodej et al. [20] have investigated the effects of compound 2 on NO production in LPS- stimulated macrophages and showed it had potent activity, with $\mathrm{IC}_{50}$ value of $66.41 \pm 5.21 \mu \mathrm{M}$. Although this structure was described more than ten years ago, research on inhibitory effect against release of $\beta$-hexosaminidase in RBL-2H3 cell lines has not been described to date. This is, therefore, the first report on antiallergic effect of compound 2.

Pectolinarigenin (compound 1) had never been reported in any of the constituent plants of BCW formulation. However, this compound has been isolated from several other plant families; Scrophulariaceae [36-38], Compositae [39-42], Bignoniaceae [43], Fabaceae [44], Verbenaceae or Lamiaceae [45-49]. Interestingly, pectolinarigenin has been isolated from Clerodendrum spp. $[46,47,49]$, related to C. petasites, a constituent plant of the $\mathrm{BCW}$ formulation. In another study, the ethyl acetate fraction of Cirsium chanroenicum (Compositae) also showed strong inhibition of COX-2mediated PGE2 and 5-LOX-mediated LT production in vitro. It showed the same inhibitory effect in several animal models of inflammation/allergy, such as arachidonic acid-induced mouse ear edema, carrageenan-induced mouse paw edema, and passive cutaneous anaphylaxis [39]. Pectolinarigenin has also been shown to have hepatoprotective activity in a rat model of hepatic injury caused by D-galactosamine (GalN) mainly via SOD antioxidant mechanism [40]. Inflammation mediators and reactive free radicals do have a role in the pathophysiology of allergic disorders, and, therefore, anti-inflammatory and antioxidant compounds often exhibit antiallergic activities.

The study on TLC chromatogram of two compounds (Figure 3), we found that compound 1 (pectolinarigenin) is presented on $H$. perforata, whereas compound 2 ( $O$-methylalloptaeroxylin) is presented on C. petasites in the same as previous reviews. Both of pure compounds show exhibited higher antiallergic activity than all fractions, BLW extract and positive control, represented in Figure 4. This preliminary study provides some supports for the use of BCW for treatment of allergic skin rash in Thai traditional medicine. This is the first report on the two isolated compounds from BCW ethanolic extract and their antiallergic activities. The ethanolic extract of BCW could be further developed into 
TABle 5: Anti-allergic activity of the ethanolic extract, fractions and pure constituents from Benchalokawichian remedy.

\begin{tabular}{|c|c|c|c|c|c|c|c|}
\hline \multirow{2}{*}{$\begin{array}{l}\text { Samples } \\
\text { Crude, semipure extracts, and pure } \\
\text { compounds }\end{array}$} & \multicolumn{6}{|c|}{ \%Inhibition at various concentrations } & \multirow{2}{*}{$\begin{array}{c}\mathrm{IC}_{50} \text { of Antiallergic activity } \\
\mathrm{IC}_{50} \pm \mathrm{SEM}, \mu \mathrm{g} / \mathrm{mL} \\
\text { ( } \mu \mathrm{M} \text { data for pure compound) }\end{array}$} \\
\hline & 0.1 & 1 & 5 & 10 & 50 & 100 & \\
\hline Ficus racemosa Linn. & - & $15.0 \pm 10.5$ & - & $28.9 \pm 9.1$ & $63.6 \pm 1.6$ & $75.8 \pm 4.3$ & $27.1 \pm 1.6$ \\
\hline Capparis micracantha DC. & - & $4.2 \pm 2.7$ & - & $9.5 \pm 7.1$ & $22.9 \pm 8.9$ & $32.3 \pm 6.3$ & $>100$ \\
\hline Tiliacora triandra Diels. & & $-24.48 \pm 5.7$ & & $-0.0 \pm 1.8$ & $11.7 \pm 4.8$ & $44.2 \pm 4.6$ & $>100$ \\
\hline Harrisonia perforata Merr. & - & $21.6 \pm 5.3$ & - & $42.4 \pm 1.3$ & $62.8 \pm 0.0$ & $78.5 \pm 0.8$ & $14.5 \pm 0.1$ \\
\hline Clerodendrum petasites S. Moore & & $-6.3 \pm 5.1$ & & $7.9 \pm 2.2$ & $44.0 \pm 1.4$ & $85.0 \pm 1.9$ & $57.8 \pm 1.4$ \\
\hline Benchalokawichian (Ha-Rak) & - & $9.7 \pm 5.5$ & - & $24.2 \pm 3.6$ & $52.1 \pm 1.5$ & $45.2 \pm 5.1$ & $39.8 \pm 1.3$ \\
\hline Fraction 1; hexane (F1) & - & - & - & - & - & - & NT \\
\hline Fraction 2 ; hexane : chloroform (F2) & - & $22.5 \pm 0.4$ & - & $30.4 \pm 2.1$ & $43.6 \pm 0.8$ & $53.0 \pm 0.7$ & $86.1 \pm 1.1$ \\
\hline Fraction 3; chloroform (F3) & - & $23.1 \pm 4.5$ & - & $40.3 \pm 3.4$ & $59.5 \pm 4.4$ & $71.2 \pm 1.7$ & $17.9 \pm$ \\
\hline Fraction 4; chloroform : methanol (F4) & - & $20.9 \pm 7.7$ & - & $38.9 \pm 3.9$ & $58.2 \pm 2.7$ & $70.5 \pm 3.7$ & $19.6 \pm 3.4$ \\
\hline Fraction 5; methanol (F5) & - & $10.5 \pm 7.6$ & - & $26.0 \pm 6.2$ & $52.1 \pm 1.5$ & $63.9 \pm 2.9$ & $39.9 \pm 1.9$ \\
\hline Compound 1; pectolinarigenin & $17.1 \pm 1.7$ & $25.1 \pm 3.9$ & $38.6 \pm 7.2$ & $101.1 \pm 9.5$ & - & - & $6.3 \pm 0.7(20.1 \mu \mathrm{M})$ \\
\hline Compound 2; O-methylalloptaeroxylin & - & $-15.8 \pm 2.3$ & $18.9 \pm 0.9$ & $40.5 \pm 0.0$ & - & $91.9 \pm 1.6$ & $14.2 \pm 0.9(51.8 \mu \mathrm{M})$ \\
\hline Chlorpheniramine $^{\mathrm{a}}$ & - & $4.0 \pm 1.9$ & - & $35.1 \pm 0.8$ & $44.4 \pm 1.8$ & $81.1 \pm 3.2$ & $16.2 \pm 2.5(58.8 \mu \mathrm{M})$ \\
\hline
\end{tabular}

${ }^{\mathrm{a}}$ Positive control.

NT (-) means not tested.

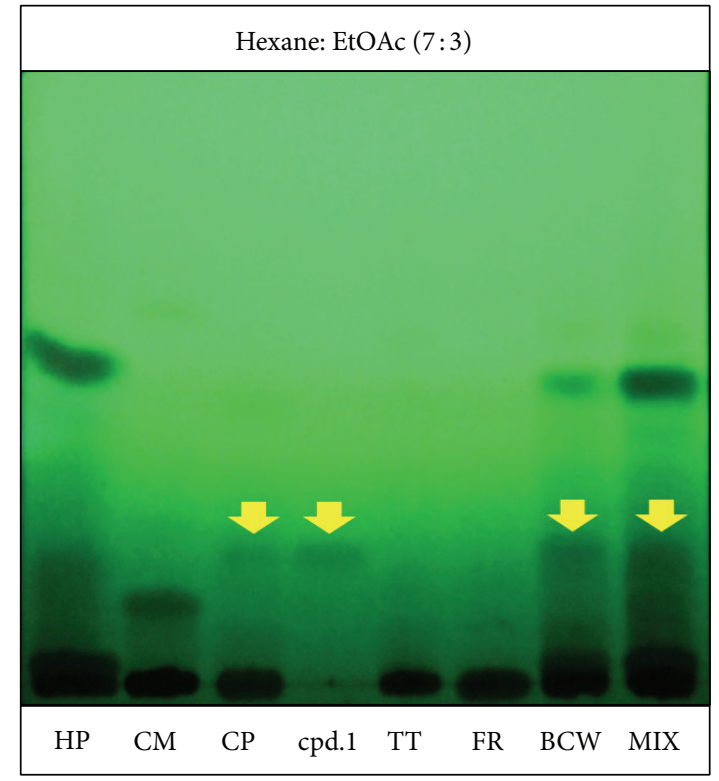

(a)

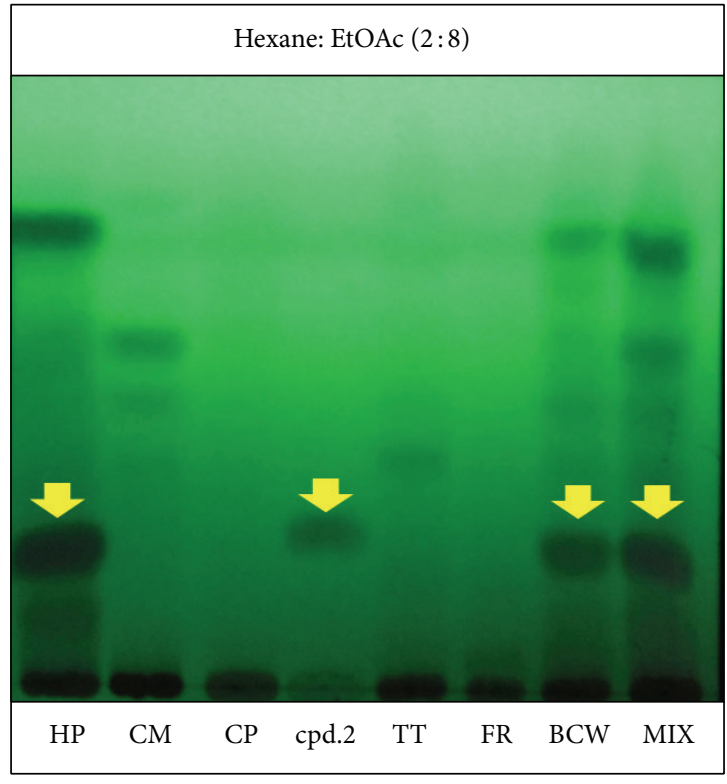

(b)

FIGURE 3: TLC chromatogram of five plants, BCW extract, mix of all extracts and pure compounds: compound 1 (a) and compound 2 (b). Note: $\mathrm{CM}=$ Capparis micracantha $\mathrm{DC} ., \mathrm{CP}=$ Clerodendrum petasites $\mathrm{S}$. Moore, $\mathrm{FR}=$ Ficus racemosa Linn., $\mathrm{HP}=$ Harrisonia perforata $\mathrm{Merr}$., and $\mathrm{TT}=$ Tiliacora triandra Diels.

commercial formulations for the treatment of allergic dermal diseases, whereas the two pure compounds can serve as bioactive markers for the analysis and standardization of any new formulated products.

\section{Conflict of Interests}

The authors declare that there is no conflict of interests regarding the publication of this paper.

\section{Acknowledgments}

This work was supported by the National Research University Project of Thailand Office of Higher Education Commission (NRU). The authors also thank the Center of Excellence in Applied Thai Traditional Medicine Research and Faculty of Medicine, Thammasat University for support and provide laboratory facilities, and Professor L. A. Damani, visiting Professor at Thammasat University, for his critical comments and careful scientific editing of this paper. 


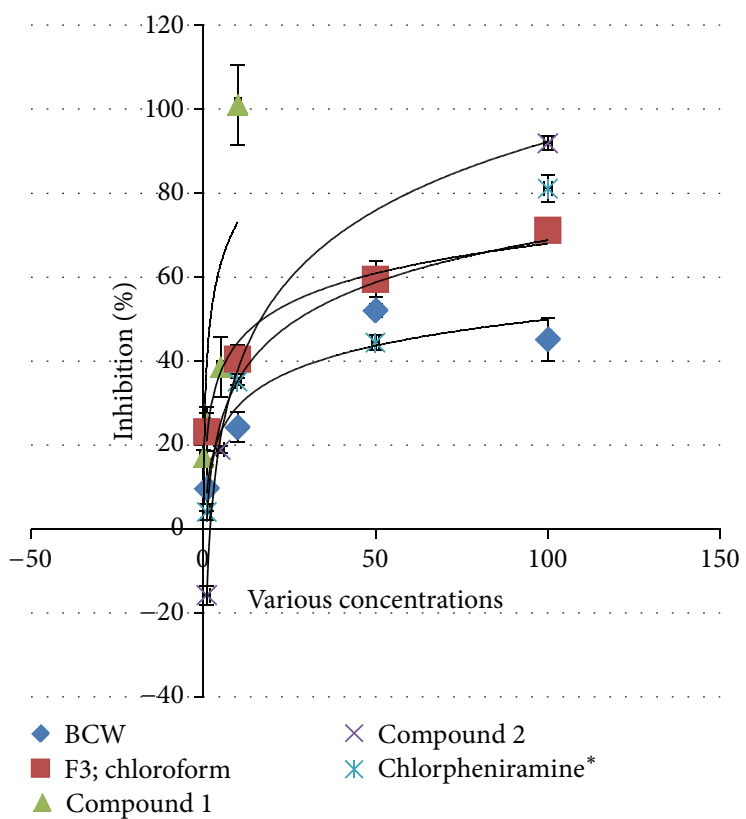

(a)

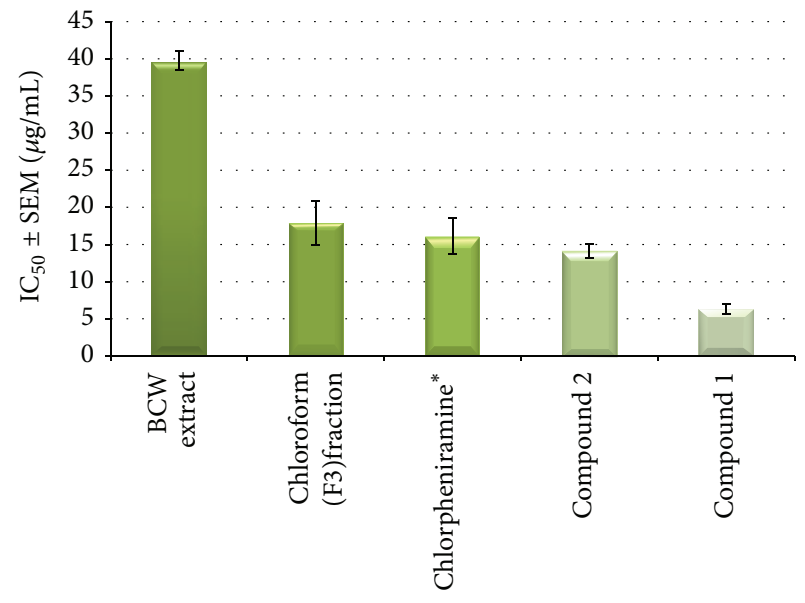

(b)

FIGURE 4: Effect of antiallergic activity against release of $\beta$-hexosaminidase in RBL-2H3 cell lines comparison of the BLW crude extract, fraction 3, pure compounds, and positive controls. (a) \% is inhibition at various concentration. (b) Data are present as the IC $\mathrm{I}_{50}(\mathrm{Mean} \pm \mathrm{SEM}$ $\mu \mathrm{g} / \mathrm{mL})$ and $*=$ positive control.

\section{References}

[1] S. T. Holgate, M. K. Church, and L. M. Lichtenstein, Allergy, Mosby, London, UK, 3rd edition, 2006.

[2] B. Alberts, A. Johnson, J. Lewis, M. Raff, K. Roberts, and P. Walter, Molecular Biology of the Cell, Garland Science, New York, NY, USA, 2007.

[3] H. Metzger, G. Alcaraz, R. Hohman, J. P. Kinet, V. Pribluda, and R. Quarto, "The receptor with high affinity for immunoglobulin E," Annual Review of Immunology, vol. 4, pp. 419-470, 1986.

[4] I. B. Haydik and W. S. Ma, "Basophil histamine release-assays and interpretation," Clinical Reviews in Allergy, vol. 6, no. 2, pp. 141-162, 1988.

[5] K. Ishizaka, T. Ishizaka, and E. H. Lee, "Biologic function of the Fc fragments of E myeloma protein," Immunochemistry, vol. 7, no. 8, pp. 687-694, 1970.

[6] T. Ishizaka, K. Ishizaka, D. H. Conrad, and A. Froese, "A new concept of triggering mechanisms of IgE-mediated histamine release," The Journal of Allergy and Clinical Immunology, vol. 61, no. 5, pp. 320-330, 1978.

[7] T. Ishizaka, D. H. Conrad, E. S. Schulman, A. R. Sterk, and K. Ishizaka, "Biochemical analysis of initial triggering events of IgE-mediated histamine release from human lung mast cells," The Journal of Immunology, vol. 130, no. 5, pp. 2357-2362, 1983.

[8] H. Bayram, J. L. Devalia, O. A. Khair et al., "Effect of loratadine on nitrogen dioxide-induced changes in electrical resistance and release of inflammatory mediators from cultured human bronchial epithelial cells," Journal of Allergy and Clinical Immunology, vol. 104, no. 1, pp. 93-99, 1999.

[9] M. M. Robinson and X. Zhang, The World Medicines Situation 2011-Traditional Medicines: Global Situation, Issues and Challenges, WHO Press, Geneva, Switzerland, 3rd edition, 2011.
[10] K. Ohmori, K. Hasegawa, T. Tamura et al., "Properties of olopatadine hydrochloride, a new antiallergic/antihistaminic drug," Arzneimittel-Forschung/Drug Research, vol. 54, no. 12, pp. 809-829, 2004.

[11] L. M. Lichtenstein, P. S. Norman, and W. L. Winkenwerder, "Clinical and in vitro studies on the role of immunotherapy in ragweed hay fever," The American Journal of Medicine, vol. 44, no. 4, pp. 514-524, 1968.

[12] D. A. Levy, "Manipulation of the immune response to antigens in the management of atopic disease in man," in Proceedings of the Conference on the Biological Role of Immunoglobulin E System, K. Ishizaka and D. H. Dayton Jr., Eds., pp. 239-245, U.S. Government Printing Office, Washington, DC, USA, 1972.

[13] F. M. Davis, L. A. Gossett, K. L. Pinkston et al., "Can anti-IgE be used to treat allergy?" Springer Seminars in Immunopathology, vol. 15, no. 1, pp. 51-73, 1993.

[14] Bureau of Drug Control (Thailand), "The Ministry of Public Health: National List of Essential Medicines," http://drug.fda.moph .go.th:81/nlem.in.th/sites/default/files/attachments/herbal_book 56.pdf.

[15] P. Tuntiwachwuttikul, P. Phansa, Y. Pootaeng-on, and W. C. Taylor, "Chromones from the branches of Harrisonia perforata," Chemical and Pharmaceutical Bulletin, vol. 54, no. 1, pp. 44-47, 2006.

[16] Q. Khuong-Huu, A. Chiaroni, C. Riche, H. Nguyen-Ngoc, K. Nguyen-Viet, and F. Khuong-Huu, "New rearranged limonoids from Harrisonia perforata," Journal of Natural Products, vol. 63, no. 7, pp. 1015-1018, 2000.

[17] Q. Khuong-Huu, A. Chiaroni, C. Riche, H. Nguyen-Ngoc, K. Nguyen-Viet, and F. Khuong-Huu, "New rearranged limonoids from Harrisonia perforata. III," Journal of Natural Products, vol. 64, no. 5, pp. 634-637, 2001. 
[18] H. D. T. Thu, M. V. Tri, N. B. Ngoc, T. Sévenet, M. Païs, and M.T. Martin, "Foritin, a new limonoid from Harrisonia perforata," Natural Product Letters, vol. 14, no. 3, pp. 191-195, 2000.

[19] S. Yin, X. Chen, Z.-S. Su et al., "Harrisotones A-E, five novel prenylated polyketides with a rare spirocyclic skeleton from Harrisonia perforata," Tetrahedron, vol. 65, no. 6, pp. 1147-1152, 2009.

[20] S. Choodej, D. Sommit, and K. Pudhom, "Rearranged limonoids and chromones from Harrisonia perforata and their antiinflammatory activity," Bioorganic and Medicinal Chemistry Letters, vol. 23, no. 13, pp. 3896-3900, 2013.

[21] D. Thaweephol, K. Panida, and N. Kazumitsu, "Isolation of active principle from Yanang," The Bulletin of the Department of Medical Sciences, vol. 16, pp. 75-81, 1974.

[22] C. Mahidol, P. Sahakitpichan, and S. Ruchirawat, "Bioactive natural products from Thai plants," International Journal of Pure and Applied Chemistry, vol. 66, pp. 2353-2356, 1994.

[23] P. Wiriyachitra and B. Phuriyakorn, "Alkaloids of Tiliacora triandra," Australian Journal of Chemistry, vol. 34, pp. 20012004, 1981.

[24] K. K. Baruah and A. K. Gohain, "Chemical composition and nutritive value of Dimaru (Ficus glomerata Roxb.) leaves," Indian Journal of Animal Nutrition, vol. 9, pp. 107-108, 1992.

[25] N. Khan and S. Sultana, "Chemomodulatory effect of Ficus racemosa extract against chemically induced renal carcinogenesis and oxidative damage response in Wistar rats," Life Sciences, vol. 77, no. 11, pp. 1194-1210, 2005.

[26] A. Konsue, J. Sattayasai, P. Puapairoj et al., "Antipyretic effects of Bencha-Loga-Wichien herbal drug in rats," Thai Journal of Pharmacology, vol. 29, pp. 79-82, 2008.

[27] A. Jongchanapong, C. Singharachai, C. Palanuvej, N. Ruangrungsi, and P. Towiwat, "Antipyretic and antinociceptive effects of Ben-Cha-Lo-Ka-Wi-Chian remedy," Journal of Health Research, vol. 24, no. 1, pp. 15-22, 2010.

[28] C. Sangrapee, S. Kantham, S. Panthong et al., "Antibacterial activity of Benchalokawichian formula," Journal of Thai Traditional \& Alternative Medicine, vol. 7, p. 121, 2009.

[29] S. Nuaeissara, S. Kondo, and A. Itharat, "Antimicrobial activity of the extracts from Benchalokawichian remedy and its components," Journal of the Medical Association of Thailand = Chotmaihet thangphaet, vol. 94, pp. S172-S177, 2011.

[30] Susan, "Study on the bioactive constitutents from Harrisonia perforata," 2013, http://www.research-degree-thesis.com/showinfo-42-398304-0.html\#sthash.jPzlWmaL.dpuf.

[31] J. Wang, M. Wang, Z. Liang et al., "Liposoluble components and their antioxidant activities from Harrisonia perforata," Journal of Tropical Agriculture, 2013, http://en.cnki.com.cn/Article_en/ CJFDTOTAL-RDNK201109011.htm.

[32] S. Sireeratawong, N. Lertprasertsuke, U. Srisawat et al., "Acute and subchronic toxicity study of the water extract from Harrisonia perforata Merr. in rats," Songklanakarin Journal of Science and Technology, vol. 31, no. 1, pp. 63-71, 2009.

[33] C. Singharachai, C. Palanuvej, H. Kiyohara, H. Yamada, and N. Ruangrungsi, "Pharmacognostic specification of five root species in Thai traditional medicine remedy: ben-Cha-Lo-KaWi-Chian," Pharmacognosy Journal, vol. 3, no. 21, pp. 1-11, 2011.

[34] S. Tewtrakul and A. Itharat, "Anti-allergic substances from the rhizomes of Dioscorea membranacea," Bioorganic \& Medicinal Chemistry, vol. 14, no. 24, pp. 8707-8711, 2006.

[35] S. Tewtrakul and S. Subhadhirasakul, "Anti-allergic activity of some selected plants in the Zingiberaceae family," Journal of Ethnopharmacology, vol. 109, no. 3, pp. 535-538, 2007.
[36] S. Thadaniti, W. Archakunakorn, P. Tuntiwachwuttikul et al., "Chromones from Harrisonia perforata (Blanco.) Merr," Journal of the Scientific Society, vol. 20, pp. 183-187, 1994.

[37] R. Tundis, B. Deguin, M. R. Loizzo et al., "Potential antitumor agents: flavones and their derivatives from Linaria reflexa Desf," Bioorganic and Medicinal Chemistry Letters, vol. 15, no. 21, pp. 4757-4760, 2005.

[38] M. Bonesi, R. Tundis, B. Deguin, M. R. Loizzo, F. Menichini, and F. Tillequin, "In vitro biological evaluation of novel 7-O-dialkylaminoalkyl cytotoxic pectolinarigenin derivatives against a panel of human cancer cell lines," Bioorganic and Medicinal Chemistry Letters, vol. 18, no. 20, pp. 5431-5434, 2008.

[39] H. Lim, K. H. Son, H. W. Chang, K. Bae, S. S. Kang, and H. P. Kim, "Anti-inflammatory activity of pectolinarigenin and pectolinarin isolated from Cirsium chanroenicum," Biological and Pharmaceutical Bulletin, vol. 31, no. 11, pp. 2063-2067, 2008.

[40] Y.-M. Yoo, J.-H. Nam, M.-Y. Kim, J. Choi, and H.-J. Park, "Pectolinarin and pectolinarigenin of Cirsium setidens prevent the hepatic injury in rats caused by $D$-galactosamine via an antioxidant mechanism," Biological and Pharmaceutical Bulletin, vol. 31, no. 4, pp. 760-764, 2008.

[41] Y. Yin, F.-Y. Gong, X.-X. Wu et al., "Anti-inflammatory and immunosuppressive effect of flavones isolated from Artemisia vestita," Journal of Ethnopharmacology, vol. 120, no. 1, pp. 1-6, 2008.

[42] A. Nugroho, S.-C. Lim, J. S. Byeon, J. S. Choi, and H.-J. Park, "Simultaneous quantification and validation of caffeoylquinic acids and flavonoids in Hemistepta lyrata and peroxynitritescavenging activity," Journal of Pharmaceutical and Biomedical Analysis, vol. 76, pp. 139-144, 2013.

[43] T. Hase, K. Ohtani, R. Kasai, K. Yamasaki, and C. Picheansoonthon, "Revised structure for hortensin, a flavonoid from Millingtonia hortensis," Phytochemistry, vol. 40, no. 1, pp. 287290, 1995.

[44] X.-G. He, L.-Z. Lin, and L.-Z. Lian, "Analysis of flavonoids from red clover by liquid chromatography-electrospray mass spectrometry," Journal of Chromatography A, vol. 755, no. 1, pp. 127-132, 1996.

[45] K. K. Seth, V. B. Pandey, and B. Dasgupta, "Flavonoids of Clerodendron phlomidis flowers," Pharmazie, vol. 37, no. 1, pp. 74-75, 1982.

[46] S. Pal, A. Chowdhury, and N. Adityachaudhury, "Isolation of rice weevil feeding inhibitors uncinatone and pectolinarigenin from Clerodendron siphonenthus," Journal of Agricultural and Food Chemistry, vol. 37, no. 1, pp. 234-236, 1989.

[47] R. J. Grayer, N. C. Veitch, G. C. Kite, A. M. Price, and T. Kokubun, "Distribution of 8-oxygenated leaf-surface flavones in the genus Ocimum," Phytochemistry, vol. 56, no. 6, pp. 559$567,2001$.

[48] R. F. Vieira, R. J. Grayer, and A. J. Paton, "Chemical profiling of Ocimum americanum using external flavonoids," Phytochemistry, vol. 63, no. 5, pp. 555-567, 2003.

[49] N. P. Babu, P. Pandikumar, and S. Ignacimuthu, "Lysosomal membrane stabilization and anti-inflammatory activity of Clerodendrum phlomidis L.f.; A traditional medicinal plant," Journal of Ethnopharmacology, vol. 135, no. 3, pp. 779-785, 2011. 


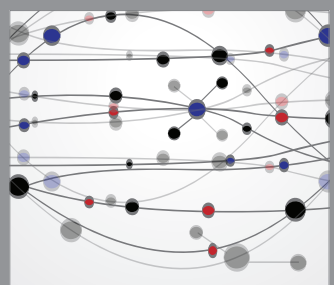

The Scientific World Journal
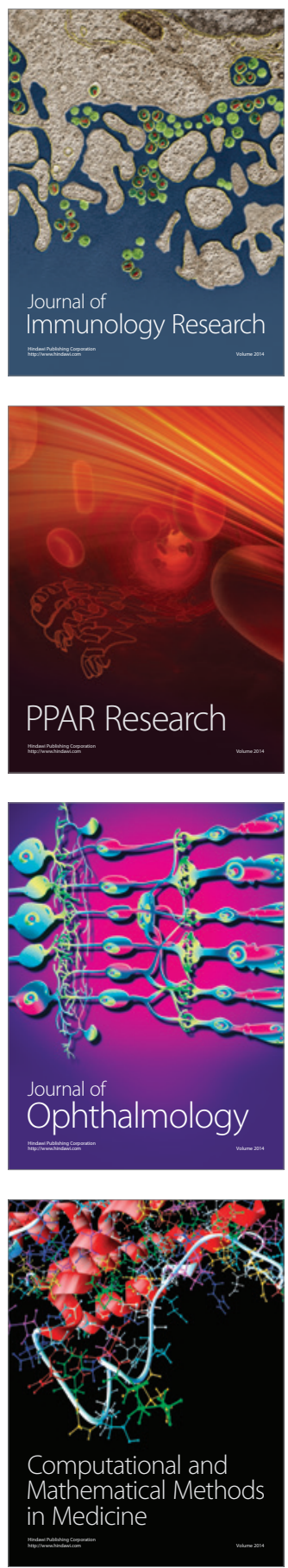

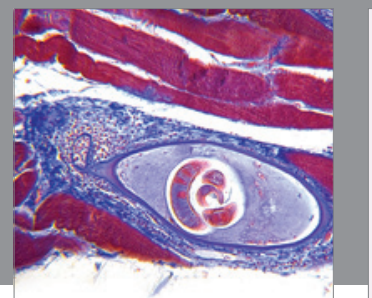

Gastroenterology

Research and Practice
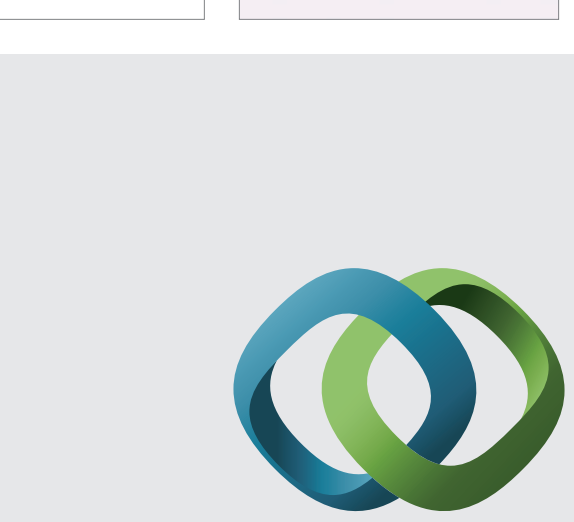

\section{Hindawi}

Submit your manuscripts at

http://www.hindawi.com
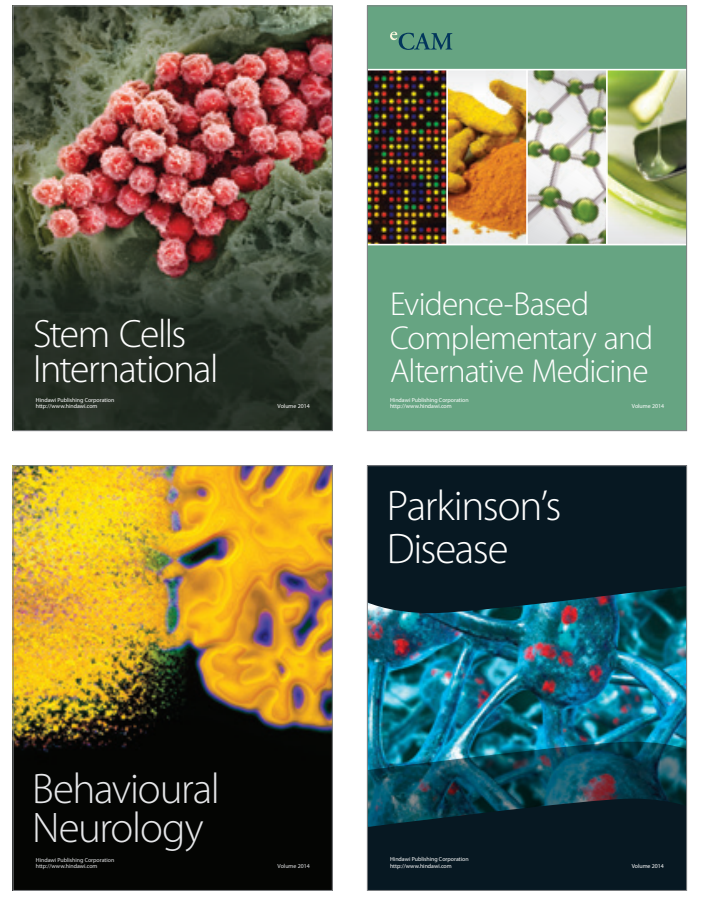
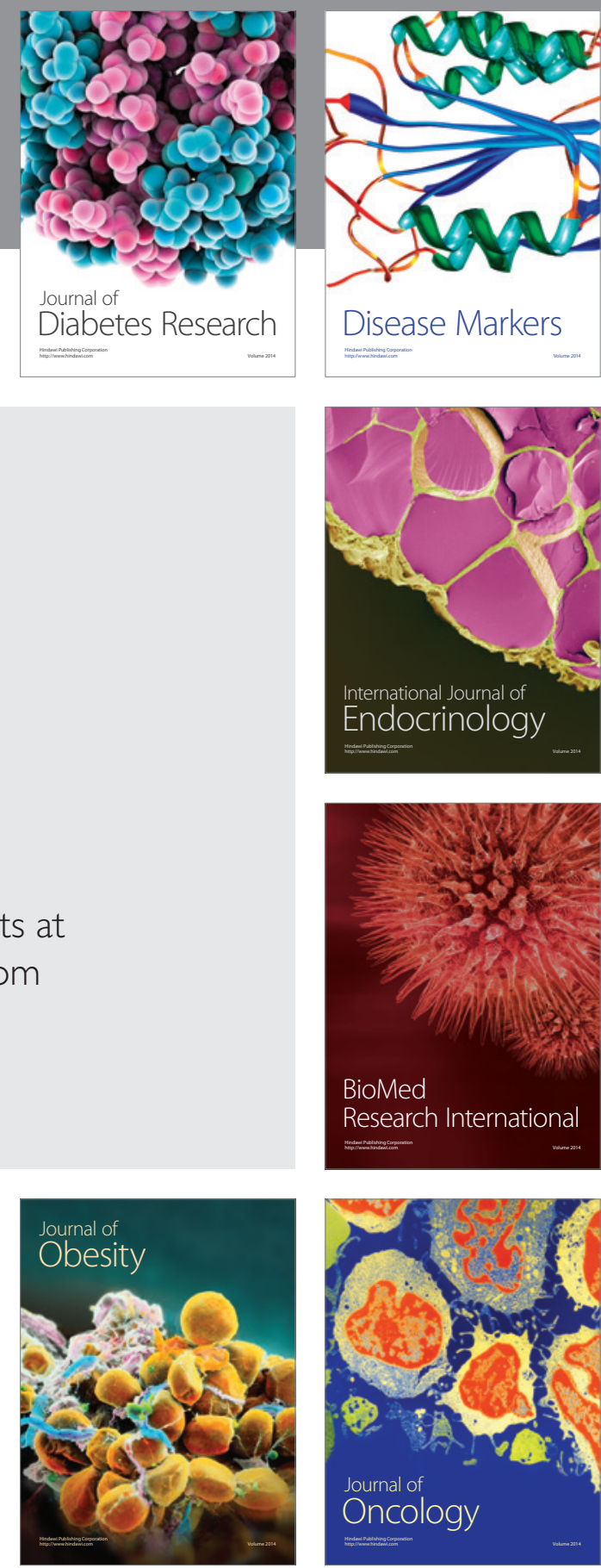

Disease Markers
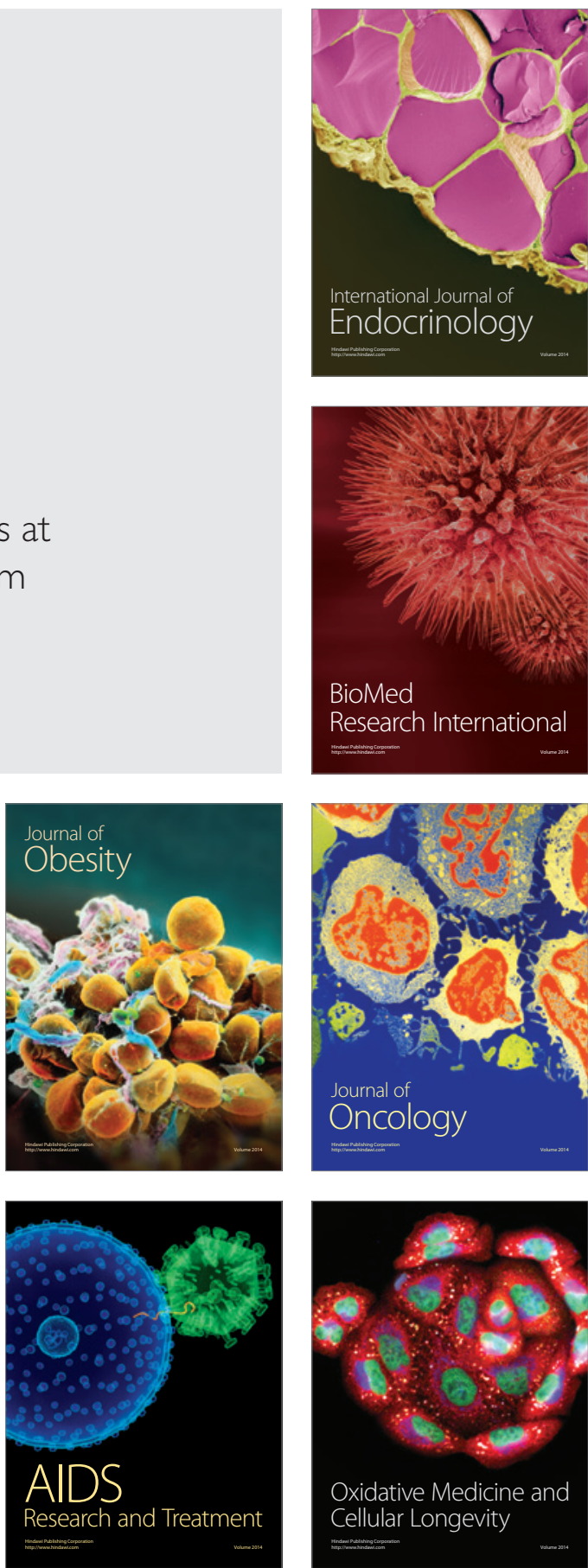